\title{
SOCIAL ADAPTATION AS AN ELEMENT OF SOCIAL POLICY
}

\author{
Venelin Terziev \\ Academician of the Russian Academy of Natural History, Moscow, Russia, Prof. D.Sc. (Ec.), D.Sc. \\ (National Security), D.Sc. (Social Activities), Ph.D., National Military University, Veliko Tarnovo, \\ Bulgaria; University of Rousse, Rousse, Bulgaria, terziev@skmat.com
}

\begin{abstract}
Dynamic changes in security environment pose serious challenges to military servicemen, discharged for one or another reason from military service, and their families. With transferring from the military to the civil sociumin their conditions of life, occur some essential changes, affecting various aspects of life: geography of the service and residence, living conditions, nature of activity, social status, level of claims to a new life, prospects for further development, circle of socialization, etc.
\end{abstract}

Keywords: social adaptation, social policy, adaptation.

\section{INTRODUCTION}

Starting basis of our research is the etymology of the term "adaptation" whose origin is from the Latin word „adaptation”, adopted in the Russian language as „adaptation” and German- „adaptation”. In the literary language it is perceived as accommodation and adjustment. In biology it expresses the accommodation of organisms to environmental conditions for existence. In the literature it is used as accommodation, adjustment of text to be understandable to readers and listeners. Refracted through the social processes, adaptation is interpreted as the accommodation of the individual to the social environment.

It is noteworthy that the concept is being studied in various fields of science, with both natural and humanitarian subjects. A more detailed review of the genesis and development of this category shows, that in greatest detail the problem of adaptation is presented and studied in biology. Starting with G. Buffon, in whose works was justified the dependence of organisms on their adaptability to the environment (although G. Buffon himself does not use the term adaptation), adaptation is the subject of study of virtually all known biologists. These are K.Ber, Veysman, Charles Darwin, N.Ya.Anilevski, K.M.Zavadski, J.B.Lamark, I.P.Pavlov, A.N.Severtsov, I.M.Sechenov, F.SentHilaire, A.D.Slonim, N.V.Timofeev-Resovski, A.A.Uhtomski, Gl.Tsaregorodtsev, I.I.Shmalgauzen and others. The entire history of the development of the theories of adaptation as a whole, reflects the struggle between the two main concepts, formulated by J.B.Lamarck and Ch.Darwin.

Jean Baptiste Lamarck explains adaptation as direct accommodation of organisms to environmental conditions. The purpose of the direct accommodation consist in the fact that the beneficial features appear in 
the organism in response to changes in the environment. Therefore, the organisms themselves and all their changes are inherently appropriate without this always being obvious. The idea is completely logical, but it is not accurate. This is because many facts cannot be explained. For example, it is impossible to explain the diversity of organisms living in the same conditions. Later J.B.Lamark developed new ideas - for the "exercisability of bodies" and "mental control on adaptation", which proved completely untenable. Subsequently the theory of J.B.Lamark, and also the various aspects and modernizations by his many followers, were named "Lamarckism”, „Jofruismm”, „psycho-Lamarckism”, „mechano-lamarckism” "determinism”, „direct adaptation”, „hard adaptation”. And the term „accommodation” is also often understood in exactly this significance.

Fundamentally different understanding of adaptation features has Charles Darwin. According to him, the changes in the body are not dependent on the environment, but are inherently arbitrary to it and are determined not only by volatility, but also by heredity of natural and artificial selection. Occasional changes, assessed by the environment as useful are being fixed, harmful ones are removed. As the environment itself is also changing in time and space, adaptations are relative and endless. The views of Charles Darwin splendidly justify the role of adaptation for the origin and development of a whole variety of organisms, the evolution of living nature, which subsequently received the name „adapto-genesis”. The theory of Charles Darwin also has many followers and is called "Darwinism”, „theory of selection”, „statistical theory of evolution”, „probability theory of adaptation”.

Basic ideas for adaptation, set and developed in biology, influence the formulation and development of this concept in a number of scientific disciplines. History of biological views on adaptation of man is practically a mirror reflection of the stages of development of sociological thought. The idea of direct adaptation to the conditions of the social environment, proved no less attractive and viable. But unlike biological disciplines, in sociology, adaptation has long time not been studied as a separate subject. In parallel with the other social sciences (philosophy, psychology, ecology, demography), in order to understand and describe the social processes, sociologists use the most significant achievements of biology, including adaptation category. Among the first to address the problem of adaptation, was the English philosopher and sociologist H.Spenser. Representing society as „social organism”, H.Spenser spread on it the laws of biological adaptation. Despite his penchant for the evolutionary theory of Charles Darwin, and his belief in the need to apply the ideas of natural selection for the ensurence of public order (social Darwinism), H.Spenser actually maintains and developsthe mechano-lamarckists direction in understanding adaptation. In his proposed „theory of equilibrium" adaptation is seen as a sustainable balance of the organism (individual) with the environment (society), in result of which public structure becomes complicated, and its "functionality" increases. The sociological views on adaptation, of other scientists in the early XX century, also developed under the influence of the doctrine of the struggle for existence and natural selection (L.Bristol, G.ChattertonHill, J.A.Tomson, M.R.Torpe).

Wide prominence received the work of the Polish-American sociologist F. Zhanetski wholooks at adaptation, through the interaction of social values (such as characteristics of the society) and social structure (such as personality characteristics). Unquestionable merit of F.Zhanetski is the idea of disclosure of the process of social adaptation by absorption of social experience by theindividual, through its "social action”, due to the way the individual experiences the social value. Studying the adaptation of Polish peasant immigrants in America U.Tomasi and F.Zhnanetski convincingly prove that the process of adaptation of the individual is primarily a social phenomenon. Taking grounds on this assertion, for the purposes of our research, object of our scientific study is the concept of "social adaptation”, understood in the broadest sense as a state of equilibriumof personality and social community. The experience of this equilibrium is a psychological phenomenon, but as a process, adaptation is filled with social content, making it the subject of economics and sociology. On this basis, the category of social adaptation is defined as an economic and sociological category.

Achieving equilibrium between the individual and the social community, implies control, internal perception of social life in its diversity and trends of development. In this sense, adaptation can be logically viewed as a unity of several aspects: moral, political, legal, socio-psychological, economic and professional. These aspects of social adaptation are attributed respectively to the different aspects of public life, in which the individual seeks himself in the sense of existence. Realization of social adaptability allows, on the one hand, a conflict-free social development of the individual, and on the other hand, leads to stabilization of the social community. The elasticity, flexibility and maturity, and thus the stability of the social systems and structures, are largely influenced by the degree of social adaptability. The degree of social adaptability is a prerequisite for the degree of active involvement of the individual in the actual life of the social community. The completed process of social adaptation is already an argument to determine the individual as a completed member of the social system, of the social organism as a whole. 


\section{SOCIO-PSYCHOLOGICAL ASPECT OF SOCIAL ADAPTATION}

Psychological manifestations and characteristics of the social environment as a whole and of its individual components (given the different social groups) are subject to study by social psychology. In the process of social adaptation, regardless of their preferences and non-preferences, the individual is dependent on the psychological manifestations of the social environment. Its adaptation to the public psyche is a multivariate process, determined essentially by the individual characteristics of the individual. The differences between the individual characteristics of the individual and the homogeneity of psychological manifestations of the social psyche, create the problem of the socio-psychological aspect of social adaptation.

Adaptation to the national psyche or to the psyche of a particular class, is mediated by micro social groups, in which the individual is included. The system of social groups has common psycho-social characteristics which give the appearance of the micro-social groups. The perception of the individual of these common characteristics passes through the socio-psychological communication in the small social groups. And this is connected with the socio-psychological aspects of adaptation, while the phenomenon of group communication is the psychological climate.

Psychologicalclimate and social adaptation are in functional dependence. The influence of the factor psychological climate on the adaptation of the individual has anattributive meaning. The psychological climate stays at the center of the socio-psychological component of adapting to each single static and temporary social group. Different definitions of psychological climate are either very large in volume, or go beyond the frame of the specific problem. Here a definition is necessary, on the basis of which the relationship between climate and social adaptation to become understandable and accurate.

Psychological climate is the result of the communication of the members of a certain micro social group, and represents a dynamic system of thoughts, feelings, attitudes and experiences of this group, regarded as a functional unit. In this sense, the psychological climate is considered the soul of a small group, of a certain community. The way the individual accepts other individuals in his emotional world, so does the community, through its inherent psychological life, accept or reject some of its members. This kind of spirituality of the micro social group acquires its durability on the basis of the proximity of the objectives, interests and needs for joint action of the individuals. Once having emerged, the psychological climate exercises its significant impact on the behavior of the members of the social group and of the group itself, as a defined whole. Generally, the psychological climate can be seen in two of its more clearly delineated variants: positive and negative manifestation of the climate. Criterion for this division is the positive or negative impact of certain micro social community on its members.

The positive value of the psychological climate reflects a conflict-free relationship, mutual respect and affection, honesty and rigor, willed determination and uncompromising. All this presupposes, and at the same time sets, a positive socio-psychological climate. In such atmosphere of communication, every individual has the opportunity to fully show their acquired knowledge, abilities and skills. The state of psychological equilibrium provides the necessary internal conditions for the perception of growing social demands, aimed at any individual. In positive psychological climate, these requirements, undisturbed by any obstructions, cleanly pass into the behavior of the individual. On this basis, the achievement of pre-made standards of conduct of the individual in society is facilitated.

The negative value of the psychological climate in the micro social group is qualitatively opposite both in content and in its function. The normal psychological equilibrium in the relationship is broken, the unity of the group is reduced, the process of labor is accompanied by psychological fatigue, there is a possibility for emerging and a resumption of conflicts. All these moments of the life of the micro social group are signs of an unbalanced, negative psychological climate. Its function contradicts the optimal requirements for collective life and work.

Both polar varieties of the value of social-psychological climate specify by itself the functional significance of the adaptation process of the individual to the public psychology.

Each micro social group has its own specific psychological climate, but this feature should not be conceived mechanically. There are common characteristics of social and psychological life, which are presented in individual micro social groups and through them develop and enrich themselves. On the basis of this mechanism is "build” the social psychology of large social groups. These general psychological characteristics are a reflection of the nature of public life in a country, of its economic, political and cultural life. Modern psychological science studies the psychology not as an absolutely independent phenomenon, but as a phenomenon strictly determinate by the particular social being of the individual. In this sense, adaptation to socio-psychological characteristics of society is also an adaptation to the political principles of this society. 
„Having passed" through the psychological life of small social groups, the social and psychological aspect of "adaptation "completes" itself as a comprehensive psychological adaptation to the macro-community of which the individual is a part (Terziev, 2018a, pp. 228-236; Stefanov, Terziev, Banabakova, 2018b, pp. 93-102; Stefanov, Terziev, Banabakova, 2018c, pp. 111-119; Terziev, Stefanov, Banabakova, 2018d, pp. 120-131; Terziev, Stefanov, Banabakova, 2018e, pp. 132-148; Terziev, 2018f, pp. 213-227; Terziev, 2018g, pp. 237247; Terziev, 2018h, pp. 256-265; Terziev, 2018i, pp. 266-276; Terziev, Latyshev, Georgiev, 2018j, pp. 248255; Glushkov, Simeonov, Georgiev, 2018k, pp. 88-92; Banabakova, Georgiev, 2017a, pp. 37-4).

\section{MORAL ASPECT OF ADAPTATION}

Every society contains a "set of principles or norms, or rules of human behavior, governing their relations to one another and to the community, to a particular group, to the state, family, etc., and supported by personal conviction, tradition, up-bringing, the power of any society or a particular group thereof. These principles or rules represent the morality of a particular type of society and exist only through this society. Moral norms reflect aspects of the social being of the people, expressed in their relationship, different for the different types of societies, as different are their economic and political principles of existence.

Ethical norms of behavior, manifested in the behavior of people, are defined as moral relations, practical morality, existing in the form of traditions, customs, habits, judg ments, evaluations, used by the people in the everyday life. Practical morality "meets" the individual from the first steps in his public life. Its manifestation are his family, school, work environment, circle of friends and acquaintances, intimate relations, etc.

Involved in the moral life, one realizes the moral aspect of adaptation to society. The wellorganized ethical theories offer convincing rules of moral conduct, but the abstraction of moral norms and laws are always perceived with understanding. This alienates their representative impact on the real behavior of individuals and social groups. On this basis the ethical aspect of adaptation in most cases passes through the problems of the issues of life and daily obstacles that accompany us. Striving for independence and preservation of a sense of dignity makes one skeptical. Only the experienced moral relationship becomes a criterion for practical moral evaluations, relative to public life, regardless of the restrictive context in which it is perceived, often within small social groups or intimate relationships.

The ethical aspect of social adaptation begins with the adoption of practical moral relationships, which not always, in each case represent a positive aspect of the moral life. This circumstance contains the risk for manifestation of negative attitude towards the moral life of the society. Practical logic is prone to generalizations of the single and the situative. The moral conflict, the immoral act, as well as the indifference in moral aspect, cause feelings and create a real basis for generalizing the moral negativity.

There also exist contrasting trends in terms of inadequate positive assessments of moral phenomena on the basis of freedom of choice of an ideal. The moral aspect of social adaptation can be expressed through the contradiction between collisions of moral relations in practical life and theoretically refined norms and laws, presented by the science of morality. Often people live all their lives perceiving their relationships with society only at psychological level. The manifestation of good and evil, balanced and immoral, are perceived by them on an emotional basis, making the actual adaptability to socially necessary way of life difficult.

The process of adoption of moral norms and laws is a process of formation of consciousness, which is related to the overall development of the individual. The following difficulties can be defined in the process of adaptation in this aspect, presented only schematicallyby us, because they are beyond the scope of this social and economic analysis. First, moral up-bringing cannot actually cover all members of a society. There are many cases where up-bringing with moral content remains something external to the object to which it is directed. Second, because of psychological instability, continuing moral conflict can cause emotional trauma, which might not go away throughout the whole life of the individual. Third, in many cases there is a discrepancy between the moral up-bringing in the family and outside it, and this contradiction significantly disturbs the process from the ethical aspect of adaptation. Fourth, the situational impacts on the human psyche (the loss of a loved one, self-blaming for an irremediable mistake, deep disappointment, etc.), are able to close the individual in himself and make him socially a-kinetic (Banabakova, Georgiev, 2018l, pp. 462-467; Terziev, 2017b, pp.517-528; Terziev, 2017c; Hristov, 2018m, pp. 277-282; Terziev, Nichev, 2017d, p.152; Terziev, Nichev, 2017e, pp.846-850; Terziev, Nichev, 2017f, p.164; Terziev, Nichev, 2017g, pp.915919; Terziev, Madanski, Georgiev, 2017h, pp.743-747; Terziev, Madanski, Georgiev, 2017i, pp.748-753; Terziev, Nichev, Stoyanov, Georgiev, 2017j, pp.690-694; Terziev, Latyshev, Georgiev, 2017k, pp.754-772; Terziev, Nikolay, Bogdanov, 2017l, pp.671-677; Terziev, Madanski, Kanev, 2017m, pp.1331-1346; Terziev, Madanski, Kanev, 2017n, pp.1355-1372; Terziev, Madanski, Kanev, 2017o, pp.1380-1393; Terziev, Madanski, Kanev, 2017p, pp.396-415; Terziev, 2017q, pp.641-653; Terziev, Nichev, 2017r, pp.627-630; 
Terziev, Madanski, Kanev, 2017s, pp.575-594; Terziev, 2017t, pp.22-28; Terziev, Nichev, 2017u, pp.646658; Terziev, Nichev, 2017v, pp.659-670; Terziev, Madanski, 2017w, pp.610-625; Terziev, Madanski, 2017x, pp.917-937).

Despite these difficulties in the realization of the moral aspect of social adaptation, we can definitely say, and this is proved by practice, that in the society there is real merge of needs and norms in certain groups.

\section{LEGAL-POLITICAL ASPECT OF SOCIAL ADAPTATION}

The social adaptation of the individual almost simultaneously with its ethical component also passes through its legal-political component. Legal and political aspects of the adaptation process are extremely close and this gives grounds to consider them together in terms of the study process. Legal norms reflect a set of rights and obligations, meant to regulate the behavior of the individuals and the functions of social institutions.

The behavior of the individual is in contact with the legal norms and this relationship is not always balanced. The problem of adaptation to the legal obligations is not solvedwith knowing and observing the legal norms, although this is a necessary stage in the adaptation process. Often it is the fear of sanctions which determines thesocial adaptive behavior, and this is just one of the fictitiousness of balance, of adaptation to the sanctioning norms of the law. The real adaptation to the legal laws is expressed in the compliance of social oriented needs of the individual with the social needs of the society.

In conclusion we can emphasize that the multi-aspectness of the category social adaptation suggests the applicability of different approaches and the need for delineation of its conceptual framework.

\section{REFERENCE LIST}

Terziev, Venelin. (2018a). Building a model of social and pshychological adaptation. // ADVED 2018- 4th International Conference on Advances in Education and Social Sciences Abstracts \& Proceedings, 1517 October 2018- Istanbul, Turkey, International Organization Center of Academic Research, www.ocerints.org, Istanbul, Turkey, 2018, pp. 228-236, ISBN: 978-605-82433-4-7.

Stefanov, S., Terziev, V., Banabakova, V. (2018b). The undertsanding of security in the postmodern society. // ADVED 2018- 4th International Conference on Advances in Education and Social Sciences Abstracts \& Proceedings, 15-17 October 2018- Istanbul, Turkey, International Organization Center of Academic Research, www.ocerints.org, Istanbul, Turkey, 2018, pp. 93-102, ISBN: 978-605-82433-4-7.

Stefanov, S., Terziev, V., Banabakova, V. (2018c). Levels of security and postmodern society. // ADVED 2018- 4th International Conference on Advances in Education and Social Sciences Abstracts \& Proceedings, 15-17 October 2018- Istanbul, Turkey, International Organization Center of Academic Research, www.ocerints.org, Istanbul, Turkey, 2018, pp. 111-119, ISBN: 978-605-82433-4-7.

Terziev, V., Stefanov, S., Banabakova, V. (2018d). Implementattion of the common european security and defence policy in the context of its military aspect. // ADVED 2018- 4th International Conference on Advances in Education and Social Sciences Abstracts \& Proceedings, 15-17 October 2018- Istanbul, Turkey, International Organization Center of Academic Research, www.ocerints.org, Istanbul, Turkey, 2018, pp. 120-131, ISBN: 978-605-82433-4-7.

Terziev, V., Stefanov, S., Banabakova, V. (2018e). Common european security and defence policy. // ADVED 2018- 4th International Conference on Advances in Education and Social Sciences Abstracts \& Proceedings, 15-17 October 2018- Istanbul, Turkey, International Organization Center of Academic Research, www.ocerints.org, Istanbul, Turkey, 2018, pp. 132-148, ISBN: 978-605-82433-4-7.

Terziev, Venelin. (2018f). Bulgarian experience in the development of social adaptation of military personnel, discharged from military service and their families. // ADVED 2018- 4th International Conference on Advances in Education and Social Sciences Abstracts \& Proceedings, 15-17 October 2018- Istanbul, Turkey, International Organization Center of Academic Research, www.ocerints.org, Istanbul, Turkey, 2018, pp. 213-227, ISBN: 978-605-82433-4-7.

Terziev, Venelin. (2018g). Opportunities of aplication of a competence-based approach in social adaptation of militaries discharged of service. // ADVED 2018- 4th International Conference on Advances in Education and Social Sciences Abstracts \& Proceedings, 15-17 October 2018- Istanbul, Turkey, 
IJASOS- International E-Journal of Advances in Social Sciences, Vol. V, Issue 13, April 2019

International Organization Center of Academic Research, www.ocerints.org, Istanbul, Turkey, 2018, pp. 237-247, ISBN: 978-605-82433-4-7.

Terziev, Venelin. (2018h). Possible aspects of occupational and psychological adaptation of the military, discharged from military service and their families to a new activity life cycle. // ADVED 2018- 4th International Conference on Advances in Education and Social Sciences Abstracts \& Proceedings, 1517 October 2018- Istanbul, Turkey, International Organization Center of Academic Research, www.ocerints.org, Istanbul, Turkey, 2018, pp. 256-265, ISBN: 978-605-82433-4-7.

Terziev, Venelin. (2018i). Realities of implementing the social adaptation process of military personnel, discharged form service in Bulgaria. // ADVED 2018- 4th International Conference on Advances in Education and Social Sciences Abstracts \& Proceedings, 15-17 October 2018- Istanbul, Turkey, International Organization Center of Academic Research, www.ocerints.org, Istanbul, Turkey, 2018, pp. 266-276, ISBN: 978-605-82433-4-7.

Terziev, V., Latyshev, O., Georgiev, M. (2018j). The warehousing as an element of army logistics system in conditions of arctics (from experience of bulgarianrussian cooperation). // ADVED 2018- 4th International Conference on Advances in Education and Social Sciences Abstracts \& Proceedings, 1517 October 2018- Istanbul, Turkey, International Organization Center of Academic Research, www.ocerints.org, Istanbul, Turkey, 2018, pp. 248-255, ISBN: 978-605-82433-4-7.

Glushkov, P., Simeonov, S., Georgiev, M. (2018k). Method of determination of the diurnal energy consumption of the cadets from the Vasil Levski National Military university. ADVED 2018- 4th International Conference on Advances in Education and Social Sciences Abstracts \& Proceedings, 1517 October 2018- Istanbul, Turkey, International Organization Center of Academic Research, www.ocerints.org, Istanbul, Turkey, 2018, pp. 88-92, ISBN: 978-605-82433-4-7.

Banabakova, V., Georgiev, M. (2017a). Problems and perspectives in Military professional education and realization of cadets in Bulgaria. // Journal of Innovations and Sustainability, Innovations and Sustainability Academy. 3, 2017, N 4, pp. 37-47, ISSN 2367-8127 (CD-ROM), ISSN 2367-8151 (online).

Banabakova, V., Georgiev, M. (2018I). Military professional forming of the cadets at Vasil Levski National Military University. // Proceedings of INTCESS2018- 5th International Conference on Education and Social Sciences 5-7 February 2018- Istanbul, Turkey, International Organization Center of Academic Research, www.ocerints.org, Istanbul, Turkey, 2018, pp. 462-467, ISBN : 978-605-82433-2-3.

Terziev, Venelin. (2017b). Opportunities and trends in the development and the improvement processes in the Bulgarian military educational system. // 3rd Central \& Eastern European LUMEN International Conference, New Approaches in Social and Humanistic Sciences NASHS 2017, Chisinau, Republic of Moldova, June 8-10, 2017, 2018, pp.517-528, ISSN (print): 2601 - 2510, ISSN (on-line): 2601 2529, ISSN-L: 2601 - 2510, ISBN: 978-1-910129-15-9.

Terziev, Venelin. (2017c). Opportunities for improving the efficiencyof the socialadaptation of servicemen discharged from military service in Bulgaria. // Catalogue of the scientific, educational and methodical literature presented by authors at the I-XXXIV All-Russian book exhibitions held by Academy of Natural History, Exposition on the Frankfurter Buchmesse 2017, XXVII, Moskow, Academy of Natural History, 2017.

Hristov, Neno. (2018m). European intervention initiative vs common European army. ADVED 2018- 4th International Conference on Advances in Education and Social Sciences Abstracts \& Proceedings, 1517 October 2018- Istanbul, Turkey, International Organization Center of Academic Research, www.ocerints.org, Istanbul, Turkey, 2018, pp. 277-282, ISBN: 978-605-82433-4-7.

Terziev, V., Nichev, N. (2017d). Research on the management skills and abilities acquired in the military education system. // CBU International Conference Book of Abstracts March 22-24, Prague, Czech Republic, Innovations in Science and Education, 2017, ISBN 978-80-88042-09-9, p.152.

Terziev, V., Nichev, N. (2017e). Research on the management skills and abilities acquired in the military education system. // CBU International Conference Proceedings 2017, March 22-24, Prague, Czech Republic, Innovations in Science and Education, 2017, SSN 1805-997X (Print), ISBN 978-80-8804207-5 (Print edition), pp.846-850.

Terziev, V., Nichev, N. (2017f). Developing the readiness for the organizational activity of the cadets. // CBU International Conference Book of Abstracts March 22-24, Prague, Czech Republic, Innovations in Science and Education, ISBN 978-80-88042-09-9, p.164. 
IJASOS- International E-Journal of Advances in Social Sciences, Vol. V, Issue 13, April 2019

Terziev, V., Nichev, N. (2017g). Developing the readiness for the organizational activity of the cadets. // CBU International Conference Proceedings 2017, March 22-24, Prague, Czech Republic, Innovations in Science and Education, 2017, SSN 1805-997X (Print), ISBN 978-80-88042-07-5 (Print edition), pp.915-919.

Terziev, V., Madanski, V., Georgiev, M. (2017h). Offset implementation impact on technology transfer in Bulgaria. // Proceedings of ADVED 2017- 3rd International Conference on Advances in Education and Social Sciences 9-11 October 2017- Istanbul, Turkey, 2017, ISBN: 978-605-82433-0-9, pp.743-747.

Terziev, V., Madanski, V., Georgiev, M. (2017i). Offset as an economic operation and a trade practice. // Proceedings of ADVED 2017- 3rd International Conference on Advances in Education and Social Sciences 9-11 October 2017- Istanbul, Turkey, 2017, ISBN: 978-605-82433-0-9, pp.748-753.

Terziev, V., Nichev, N., Stoyanov, E., Georgiev, M. (2017j). A general principle of the development process of balanced scorecards as an instrument of control. // Proceedings of ADVED 2017- 3rd International Conference on Advances in Education and Social Sciences 9-11 October 2017- Istanbul, Turkey, 2017, ISBN: 978-605-82433-0-9, pp.690-694.

Terziev, V., Latyshev, O., Georgiev, M. (2017k). Building competencies for social work through continuing vocational training. // Proceedings of ADVED 2017- 3rd International Conference on Advances in Education and Social Sciences 9-11 October 2017- Istanbul, Turkey, 2017, ISBN: 978-605-82433-0-9, pp.754-772.

Terziev, V., Nikolay, N., Bogdanov, P. (2017I). Comparative analysis of the formation of military professional skills in the cadets to be trained in logistics specializations. // Proceedings of ADVED 2017- 3rd International Conference on Advances in Education and Social Sciences 9-11 October 2017- Istanbul, Turkey, 2017, ISBN: 978-605-82433-0-9, pp.671-677.

Terziev, V., Madanski, V. Kanev, D. (2017m). Entry opportunities in the Bulgarian military-educational system. // Sport, Education and Society, Taylor \& Francis, 22, 2017, N 8(2), Source Normalized Impact per Paper (SNIP): 1.459 SCImago Journal Rank (SJR): 1.005 Impact factor: 1.269 Ranking: 60/230 (Education \& Educational Research), 20/44 (Hospitality, Leisure, Sport and Tourism), 51/82 (Sport Sciences), Print ISSN: 1357-3322 Online ISSN: 1470-1243, pp.1331-1346.

Terziev, V., Madanski, V., Kanev, D. (2017n). Condition and capabilities of the military-educational system of the Republic of Bulgaria. // Sport, Education and Society, Taylor \& Francis, 22, 2017, N 8(2), Source Normalized Impact per Paper (SNIP): 1.459 SCImago Journal Rank (SJR): 1.005 Impact factor: 1.269 Ranking: 60/230 (Education \& Educational Research), 20/44 (Hospitality, Leisure, Sport and Tourism), 51/82 (Sport Sciences), Print ISSN: 1357-3322 Online ISSN: 1470-1243, pp.1355-1372.

Terziev, V., Madanski, V., Kanev, D. (2017o). Directions for improvement of the military-educational system and its contribution for strengthening national security and the defence of the country. // Sport, Education and Society, Taylor \& Francis, 22, 2017, N 8(2), Source Normalized Impact per Paper (SNIP): 1.459 SCImago Journal Rank (SJR): 1.005 Impact factor: 1.269 Ranking: 60/230 (Education \& Educational Research), 20/44 (Hospitality, Leisure, Sport and Tourism), 51/82 (Sport Sciences), Print ISSN: 1357-3322 Online ISSN: 1470-1243, pp.1380-1393.

Terziev, V., Madanski, V., Kanev, D. (2017p). Entry opportunities in the bulgarian military-educational system and ensuring of civil rights. // IJAEDU- International E-Journal of Advances in Education, 3, 2017, N 8 , e-ISSN:2411-1821, pp.396-415.

Terziev, Venelin. (2017q). The needs of continuing vocational training of social work specialists providing social services. // Proceedings of SOCIOINT 2017- 4th International Conference on Education, Social Sciences and Humanities 10-12 July 2017- Dubai, UAE, 2017, ISBN: 978-605-82433-1-6, pp.641-653.

Terziev, V., Nichev, N. (2017r). Analysis of the environment for military educational system functioning and its impact on the preparation of cadets for military professional activities in the republic of Bulgaria. // Proceedings of SOCIOINT 2017- 4th International Conference on Education, Social Sciences and Humanities 10-12 July 2017- Dubai, UAE, 2017, ISBN: 978-605-82433-1-6, pp.627-630.

Terziev, V., Madanski, V., Kanev, D. (2017s). Entry opportunities in the bulgarian military-educational system and ensuring of civil rights. // Proceedings of SOCIOINT 2017- 4th International Conference on Education, Social Sciences and Humanities 10-12 July 2017- Dubai, UAE, 2017, ISBN: 978-60582433-1-6, pp.575-594.

Terziev, Venelin. (2017t). National security of the republic of Bulgaria. // International Journal of Management 
and Applied Science, 3, 2017, N 4, ISSN: 2394-7926, pp.22-28.

Terziev, V., Nichev, N. (2017u). Research of the value orientation and structural peculiarities of management activitiesofcadets in the course of military professional training. // Proceedings of the VII International Academic Congress „Fundamental and Applied Studies in EU and CIS Countries” (United Kingdom, Cambridge, England, 26-28 February 2017), Cambridge University Press, 7, 2017, ISBN: 978-0-87583597-4, pp.646-658, Source Normalized Impact per Paper (SNIP): 5.192 SCImago Journal Rank (SJR): 5.186 Impact factor: 7.549 .

Terziev, V., Nichev, N. (2017v). Research of the motivation for management activities of cadets in the course of their military professional training. // Proceedings of the VII International Academic Congress „Fundamental and Applied Studies in EU and CIS Countries” (United Kingdom, Cambridge, England, 26-28 February 2017), Cambridge University Press, 7, 2017, ISBN: 978-0-875-83597-4, pp.659-670, Source Normalized Impact per Paper (SNIP): 5.192 SCImago Journal Rank (SJR): 5.186 Impact factor: 7.549 .

Terziev, V., Madanski, V. (2017w). Guidelines for development of military education system in Bulgaria. // Proceedings of the VII International Academic Congress "Fundamental and Applied Studies in EU and CIS Countries" (United Kingdom, Cambridge, England, 26-28 February 2017), Cambridge University Press, ISBN: 978-0-875-83597-4, 7, 2017, pp.610-625, Source Normalized Impact per Paper (SNIP): 5.192 SCImago Journal Rank (SJR): 5.186 Impact factor: 7.549.

Terziev, V., Madanski, V. (2017x). Development of military education system in Bulgaria. // American Journal of Education, The University of Chicago Press, 2017, 123, 2017, N 4 (2), ISSN: 0195-6744, pp.917937, Source Normalized Impact per Paper (SNIP): 1.653, SCImago Journal Rank (SJR): 2.243. 